\section{Conquest through biology}

Roy Porter

Ecological Imperialism: The Biological Expansion of Europe, 900-1900.

By Alfred W. Crosby.

Cambridge University Press:1986. Pp.367. Hbk£27.50, \$22.95; pbk $£ 9.95$.

TODAY the developed nations tower over the Third World rather as Gulliver over the Lilliputians. But it was not always so. Indeed the early centuries of European colonial expansion have a David and Goliath quality. How did a few pioneers from a small continent succeed in conquering the oceans, and then all the vast expanses of the Americas, Australasia and much of Africa as well? How did stout Cortés with his handful of men bring the vast Aztec empire of Central America to its knees and wrest its treasures for Spain? How did the flight of a few pious Pilgrim Fathers lead to the decimation of the Red Indians and the opening of a whole continent for the White Man?

The conventional answer to this seeming paradox is that Europeans had overwhelming superiority in science, technology and military might. Caravels, maps, sextants, quadrants, compasses, and above all guns, from the ancient arquebuses to deadly Remingtons, gave the intrepid peoples of the Atlantic seaboard the capacity to come, see and conquer. There is no disputing that, confirms Professor Crosby: could anyone who has ever seen a Western deny that in the long run bows and arrows are no match for rifles, let alone Gatling guns? But the stunning success of European colonization depended on much more than that; in fact, upon a deeper biological and epidemiological "fire power", which Crosby proceeds to explore in this profoundly illuminating and often moving book.

The global success story of the White Man was a true triumph of Darwinian natural selection. When, from the late Middle Ages onwards, Europeans swarmed out from their overcrowded continent, they chiefly put down roots, as might be expected, not at the sterile polar wastes nor in lethal equatorial forests, but in the great open spaces of temperate grassland the globe afforded: almost the whole of North America, much of Middle America, the pampas of South America, the steppes of Siberia, the southern part of

Africa, and Australia and New Zealand. These offered paradise environments, requiring relatively little acclimatization or adjustment of basic European techniques of pastoralism and agriculture. Moreover, these regions of "Neo-Europe" also afforded an ideal biological niche for the invaders.

For, thanks to continental drift, the "splitting of the seams of Pangaea" had left the virgin continents extraordinarily vulnerable. Their natives, such as the Maoris, though often populous, were stuck in the time-warp of the Stone Age and could not compete with European arms, ploughs and liquor. Some - like the Guanches of the Canary Islands (scene of one of the first colonialist triumphs) or the Tasmanians - disappeared altogether from the face of the Earth; others, like the Aborigines, dwindled in numbers to

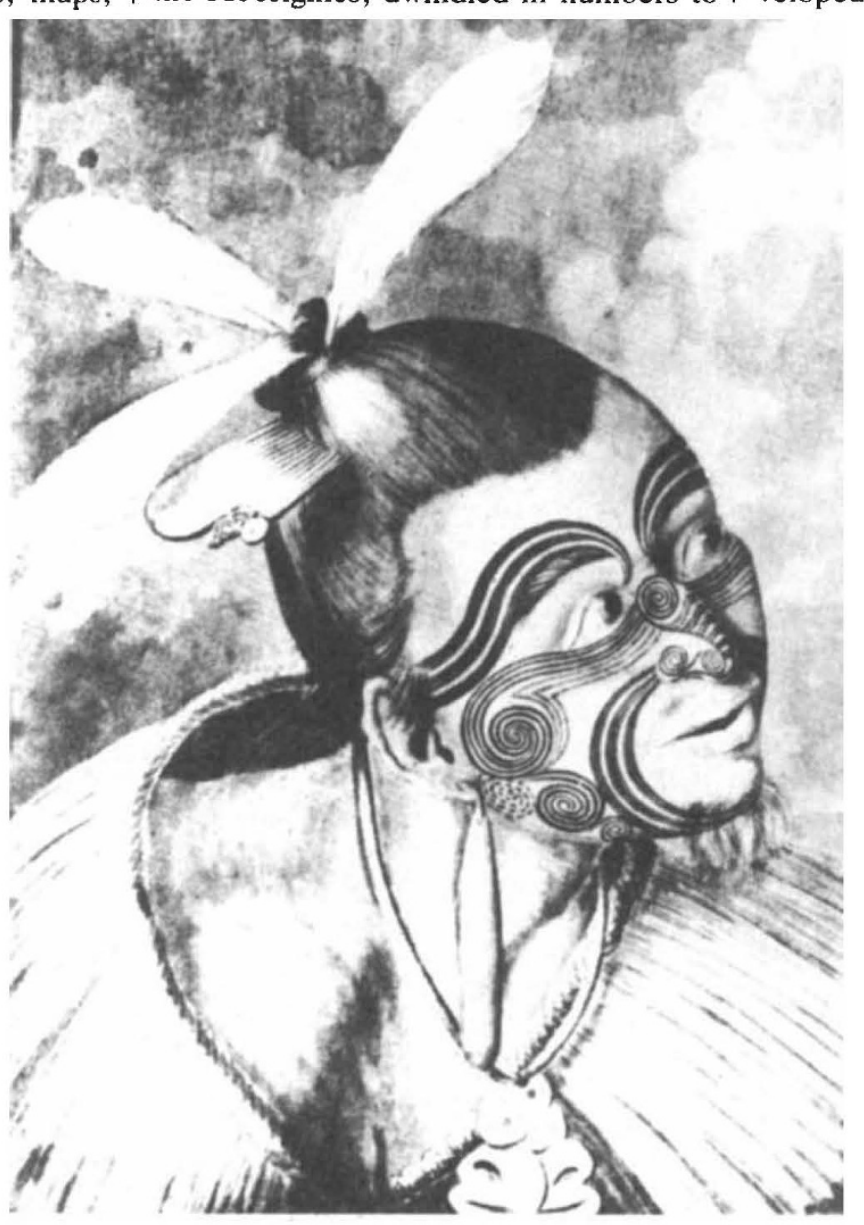

Facing ruin - a Maori depicted by one of the artists on James Cook's 1768 expedition to the Pacific. (Reproduced from Ecological Imperialism.) become shadows of their former selves.

Neither could their flora and fauna compete. The Americas and Australasia did not simply have highly distinct biota. By and large, they specifically lacked powerful and predatory creatures. The pampas with its flightless birds and Australia with its kangaroos were "vacated econiches", wide open and exceptionally hospitable to the horses, pigs, cattle and sheep the White Man brought by design, and to the rats and other vermin he brought by accident. Helped by the introduction of hardy grasses, European livestock, wild and domesticated, throve in the Neo-Europes, and ensured settlers, fleeing from Malthusian nightmares of starvation in the Old Continent, a luxury seat at Nature's feast.

What ultimately tipped the balance, ho'vever, was disease. The colonist and his beasts marched into continents which were amazingly disease-free. But with them they brought all the killer parasites and pathogens associated with filthy, congested, urban Europe, with ports, ships and sailors. The crack troops of the invaders were TB, scrophula, typhus, whooping cough, measles and so forth - microorganisms to which Europeans had developed considerable immunity but which proved catastrophic to populations exposed to them for the first time. Smallpox destroyed the Amerindians of the pampas, the Aborigines, the indigenes of Siberia; syphilis ruined the Maoris. Before the "magic bullet" came the White Man's "magic bacteria". If nowadays we see our destiny depending on the fight against disease, we do so precisely because, in the past, disease was our ally in assuring the ascendency of our particular civilization.

Medicine and history, biological and cultural evolution, plagues and peoples are still all too often studied apart from each other, fractured by a stultifying "cultural drift". In his two previous studies, one on the ecological consequences of Columbus's travels, the other on the deadly influenza at the close of the First World War which claimed more victims than the War itself, Professor Crosby has shown that this gap between microbes and men can be bridged. In this latest work, uniting scholarship and speculation, he has unfolded with great power the wider biopolitics of our civilization.

Roy Porter is at the Wellcome Institute for the History of Medicine, 183 Euston Road, London NWI 2BP, UK. 